This item is the archived peer-reviewed author-version of:

Trade, political coalitions and Neo-Gothic architecture

\title{
Reference:
}

De Bièvre Dirk.- Trade, political coalitions and Neo-Gothic architecture

European review : interdisciplinary journal of the Academia Europaea / Academia Europaea - ISSN 1474-0575 - 27:2(2019), p. 175-186 Full text (Publisher's DOI): https://doi.org/10.1017/S1062798718000753 
Author version of De Bièvre, Dirk (2019), 'Trade, political coalitions, and neo-gothic architecture in Europe', European Review 27(2): 175-186.

Abstract

Why did 19-th Century English Lords build Gothic ruins, Flemish-Belgian textile barons recreate medieval cities, and Prussian elites invent industrial knights' castles? In this essay, I provide an explanation for these very different shades of neo-gothic architecture in Europe from a political economy perspective. Elites in these industrialising countries depended on very different types of trade, occasioning them to choose very different reinterpretations of medieval European gothic architecture. The different political coalitions making up the elites of these countries led the neogothic wave to be bourgeois-urban in Great Britain, urban-catholic in Belgium and militaryaristocratic in Prussia and the Rhineland.

\section{Trade, political coalitions, and neo-gothic architecture}

Why did English lords build Gothic ruins, did Flemish textile barons recreate medieval cities, and did the Prussian elites restore castles?

Neo-gothic architecture is normally portrayed as an architectural movement originating in England in the late $18^{\text {th }}$ Century, that spread out over the entire European Continent in the course of the $19^{\text {th }}$ Century. As with the adoption of modern forms of the State, it is often suggested that the nations of Europe embraced a uniform Neo-Gothic style. Actually, however, just as their modern political regimes took on substantially different characteristics, so did the elites of the various European countries adopt markedly different Neo-Gothic styles to symbolize their power. Great Britain had an economy that industrialized early and was strongly dependent on trade, as well as a liberal democracy that saw a rapid expansion in suffrage rights. The new elites that profited from these developments slowly replaced the landed aristocracy as the bastion of power, and imposed bourgeoisie ideas on the architecture of the buildings that intended to display their power. By contrast, the predominantly agrarian and aristocratic elites of the emerging German state co-opted the new industrial elites, and held the liberalization of trade that was so transforming Great Britain at bay. They gave Germany's Neo-Gothic style a more aristocratic, knightly, and authoritarian character. In Belgium the unholy alliance between the catholic, rural elites, predominantly from the densely-populated area of Flanders, on the one hand, and the increasingly powerful bankers from Brussels and the Wallonian industrial elites on the other hand, had led to the creation of a liberal monarchy - as a form of government, really a contradictio in terminis. The two partners to this marriage managed, just as the reformers in Great Britain, to obtain extensive trade liberalization. The Catholic arm of the Belgian elites from then on chose resolutely for an urban, medieval-colored Neo-Gothic style to symbolize its power. 
In this essay I want to explain why these three countries adopted various national forms of Neo-Gothic architecture. I build on the argument that Ronald Rogowski develops in Commerce and Coalitions: How Trade Affects Domestic Political Alignments. In this book, Rogowski illustrates how the extent of a country's dependence on trade in large part was responsible for the types of political coalitions that were formed (Rogowski 1989). The author connects the degree of trade dependence with respect to the three economic production factors, land, labor, and capital, to the subsequent growth or decline of the farmers and estate-owners, laborers, and capitalists, and this, in turn, to the nature of the political coalitions that emerged. The fact that countries can vary in the amount of land, capital, and laborers that they possess relative to other countries, affected the coalitions forged between the elites of each of these three key societal groups. The composition of these coalitions was different in Great Britain, newly founded Belgium, and the Prussian-dominated German Reich, and each of these coalitions put their own distinctive mark on Neo-Gothic architecture in their countries.

\section{Industrial knight's castles and the Reichsgründerzeit-elite}

German Neo-Gothic architecture was, in contrast to the bourgeois and urban styles that dominated Belgium and Great Britain, aristocratic and militaristic. In addition, it was by no means the most dominant architectural movement in the German speaking part of Europe, most certainly not in Prussia, but also not in the later-formed German Reich. In Prussian Berlin, for instance, the Neo-Classical style was predominant. It was Prussia's friendly threats of war which ensured that the Zollverein was able to expand southwards and incorporate various small principalities. In contrast to Prussia, which was ruled by Protestant Junker landowners and elites from the military and aristocracy, various of these southern states were much more Catholic, and some had also recently industrialized. Particularly the large industrialists in the Rheinland and the Ruhrgebiet actually welcomed the expansion by the Prussian-governed Zollverein, as it implied the abolition of local rights to levy customs duties. This liberalization of intra-German trade was the perfect way to push through with the process of German industrialization that took on a dazzling momentum between 1870, when the Empire was created, and 1914. And it was these industrialists that were responsible for re-inventing, rebuilding, and sometimes even building entirely new, so-called legendary Rhein Schlösser. Since the State elite, consisting of the aristocracy and the military, had successfully squashed any bourgeoisie aspirations to participation in government, such as in the revolution of 1848, the leading classes could indulge without inhibitions in the authoritarian symbolism of the absolute rule of knights. After the industrialists had ensured that the Rhine was navigable, particularly for Dampfschiff from 1827 onwards, the idea of a romantic Rhein from Mannheim to Cologne could take flight. Previously, the Rhine had just been a pesky and unreliable river: Flöser, transporters with wooden rafts, used it to ply their paltry trade, at least if the water level allowed it. But by the beginning of the nineteenth century, the river had been transformed to the main artery of German inland trade, and allegedly centuries-old castles that adorned it were said to build the heart of the German Empire. The later construction of the Rheinschiene on which freight trains bursted through the Rhine valley, made the landscape 
of the Loreley extremely popular. This popularity was buttressed by its mythical depictions in the works of various painters.

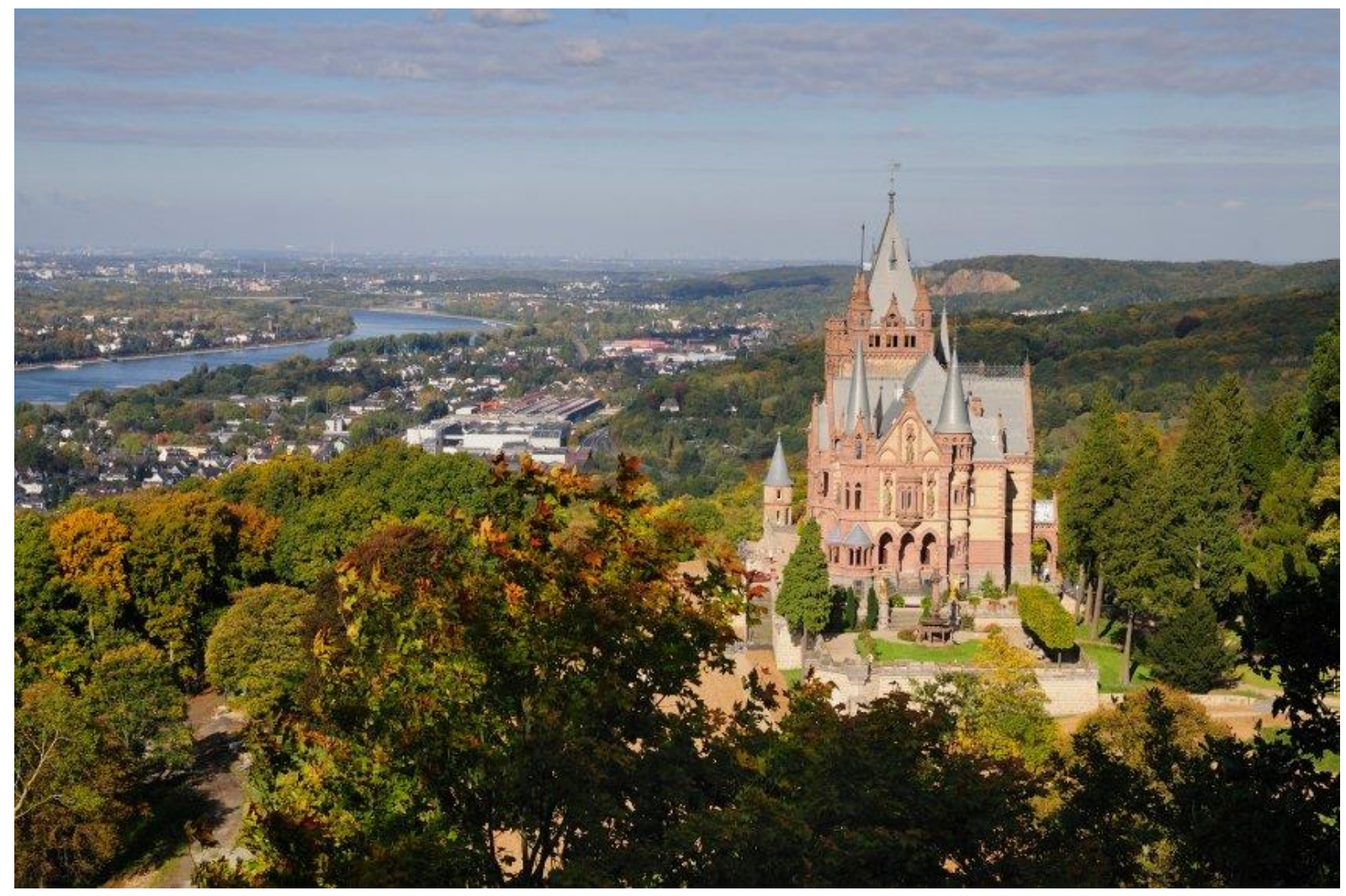

Illustration 1: Schloss Drachenburg in Königswinter nearby Bonn, built at a record pace (18821884) by Stephan von Sarter, a Parisian stock trader and financier who was originally from Bonn, and later also became a baron.

The large industrialists behind the steel skeletons of the Neo-Gothic Burgen did not need to bother much with democratic aspirations and social mobility of the lower classes within the authoritarian regime of the Empire created in 1870. The glorification of the idea of knighthood from medieval culture could blossom freely. As pseudo aristocrats with an industrial source of income, they set aside the bourgeoisie and urban style of the High Middle Ages, and created through their architecture the image of almighty lords that had for centuries been entitled to power and to stand above the vulgum plebs in the Vineyards, fields, and forests.

These upper-bourgeoisie and aristocratic elites instructed the lower German bourgeoisie to cap their aspirations, excluded them from the cenacles of state power, and impeded the rise of the large-scale urban and bourgeoisie Neo-Gothic style that marked Belgium and Great Britain. The debacle of the failed liberal revolution of 1848 and the subsequent persecutions drove many lower bourgeoisie to a type of apolitical innere Emigration and into the literary salons, giving rise to the impressive theater and music scene so typical of German cities of the time. Soon after he had stood in the revolutionary barricades of Dresden in 1848, for instance, the musical and theatrical producer Richard Wagner began absolutizing art as mankind's 
ultimate calling: the Gesamtkunstwerk was the new religion and highest good, higher than the mere materialistic, socio-economic, and political emancipation of the Burghers. What a contrast with the socio-economic mobility and political power seeking Bourgeoisie of Belgium and Great Britain! And just to briefly continue on the remarkable transformation of the Rhine: in Wagner's Rheingold, it is not at all a symbol of the naiveté and romance in nature, but rather of the romantic tensions between the violence of natural forces and their submission by man in the industrial age.

The urban Neo-Gothic style of the Kölner Cathedral was also realized during the aristocraticmilitaristic Prussian regime, this in an attempt to win over the Catholic industrial elites of the Rhineland. However, in the context of the Kulturkampf, the archbishop was absent from the inauguration, as the German Emperor was protestant. The two sandstone spires on the west side of the cathedral that tower above the Rhein from the center of the city are an attempt to embody the late Gothic style of the Middle Ages. Nevertheless, these professionally sculpted sandstones are adeptly fastened to an industrial, steel construction that finds it equal in the Eiffel Tower.

The list of relevant German buildings expands to other types of Neo-Gothic styles. For instance, the Marienburg, the summer residence of the Welfen family built between 1857 and 1867 in between Hannover and Hildesheim, is one large Neo-Gothic knight's castle invention. There are no cities in sight anywhere. Only the small, schmucke Hildesheim is in the neighborhood. The geographic location evokes the illusion of desolate woods and pastoral tranquility, protected by an art-loving and devoted chivalric order. 


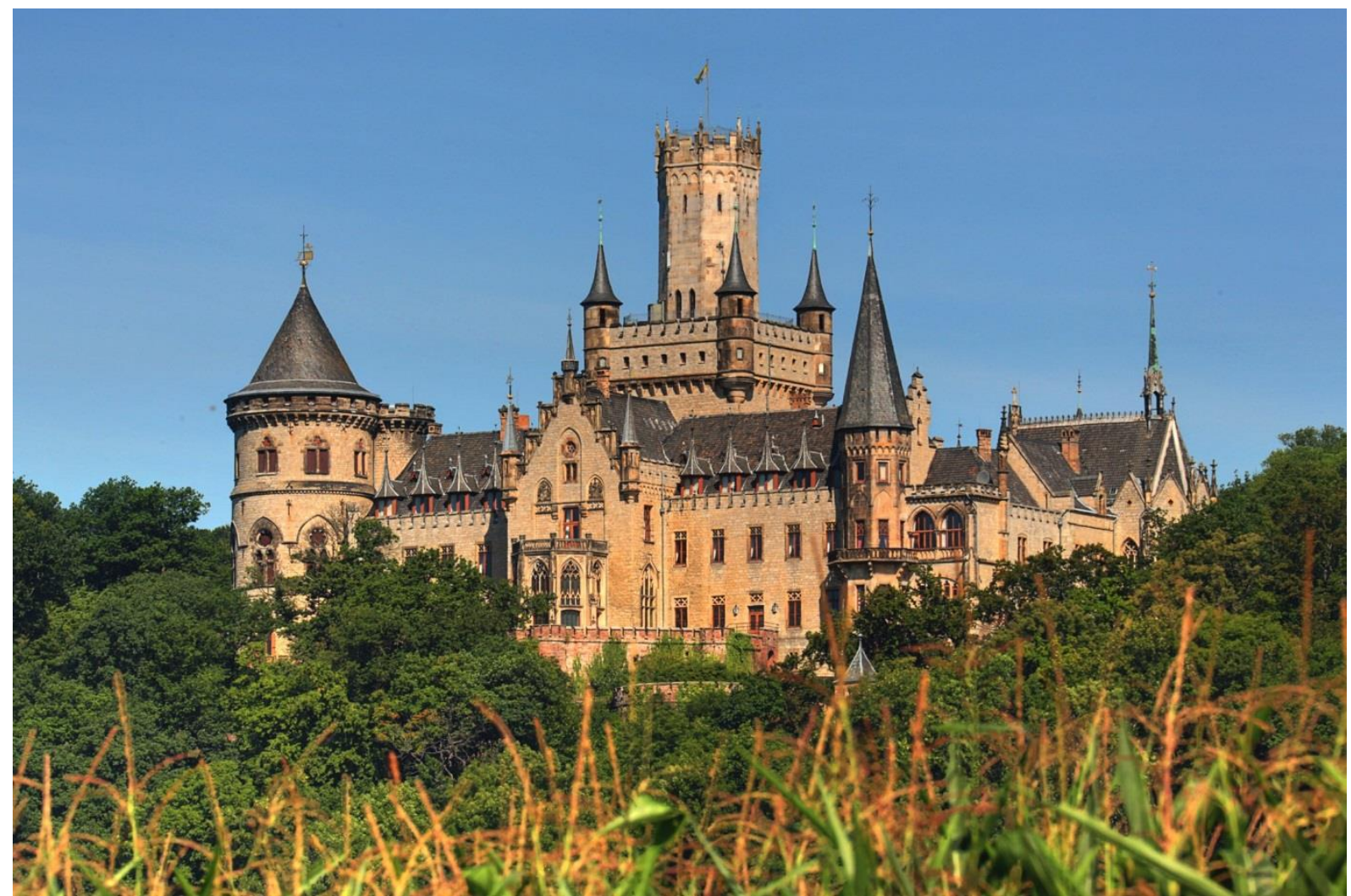

Illustration 2: Schloss Marienburg nearby Hannover, built by King Georg V von Hannover (185767)

And, of course, we cannot forgo the Schlösser-fantasy of Ludwig II von Bayern. This eccentric combined a passion for industrial building methods and new technological gadgets such as electricity, lifts, and theater machinery, with a somewhat emotional promotion and creditfinanced subsidization of the trades concerned with Neo-Gothic splendor and grandeur.

\section{Urban Neo-Gothic architecture and Belgian Catholicism}

How different the urban character of the Neo-Gothic style in Flanders, and Belgium more generally. Even though the aristocracy did build small Neo-Gothic castles here and there and sometimes renovated existing estates, its Neo-Gothic style was predominantly a re-invention of the medieval cities of Flanders and Brabant. The Flemish city of Brugge had long before become an impoverished and run-down city, before the textile barons and the ecclesiastical elites reinvigorated it with a grand Neo-Gothic building campaign. In fact, most of its inner city does not stem from the Middle Ages, but from the nineteenth century. In Gent, former seat of the count of Flanders and birthplace of the Saint Lucas school that would institutionalize the Belgian Neo-Gothic architectural movement, a fantasy Gothic building was erected as late as 1903 in the city center, namely a post office and hotel with tower, right next to the medieval ensemble of staple houses at the quays of Leie river, the Saint-Nicolas church, the Belfry, and Saint-Bavo cathedral. 


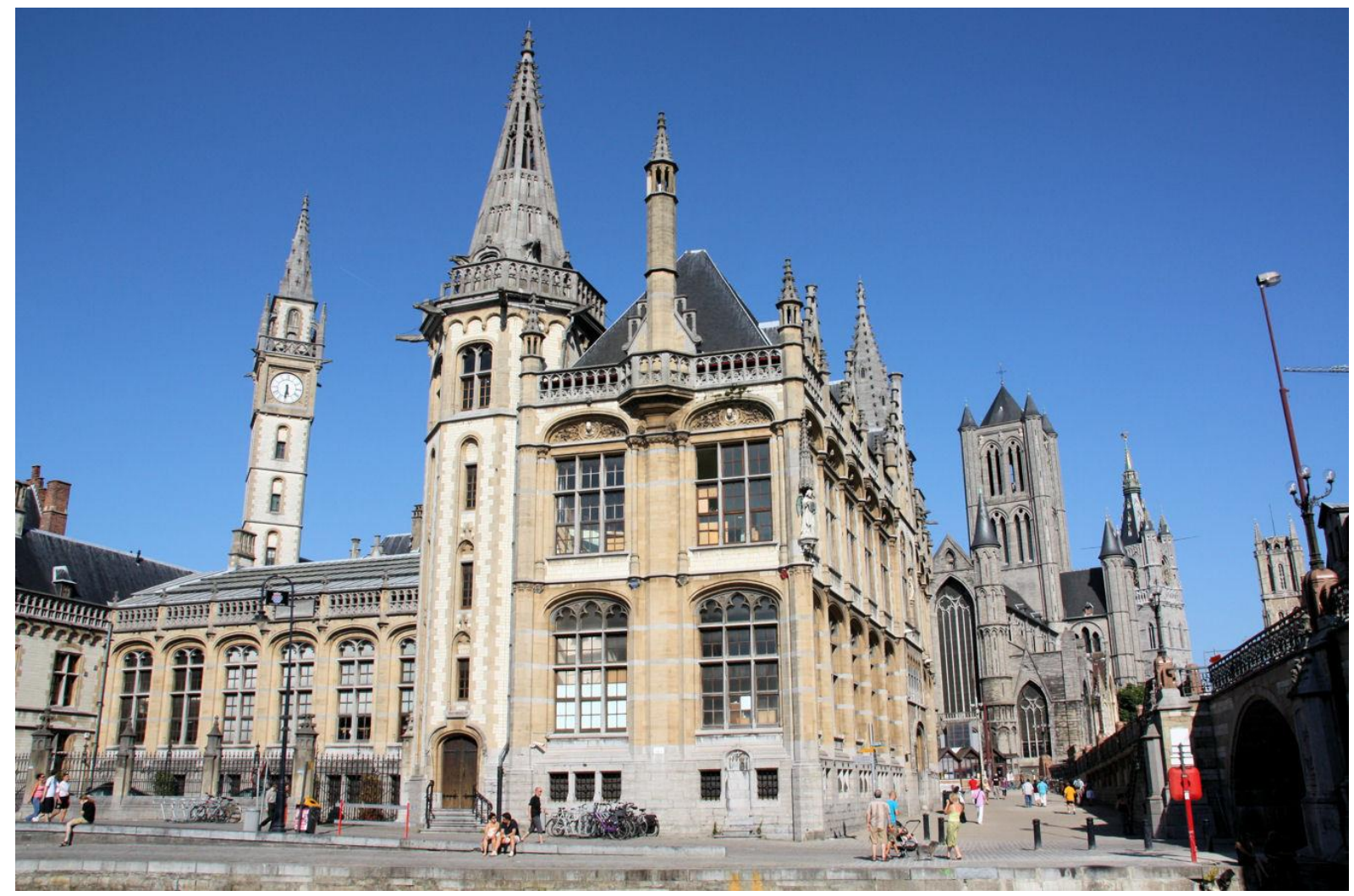

Illustration 3: Old post office from 1903, Graslei, Gent: let's build some more towers

When the University of Leuven, in the former duchy of Brabant, was opened again in 1835 after the French revolutionary years, it was engulfed by the large nineteenth century, NeoGothic building spree. The constitutionally guaranteed freedom of religion ensured a very beneficial financial charter for the university, given that all its clergy professors were paid by the Ministry of Justice. In this way, the church could, complemented by state support, invest the income from its lands, real estate, and early investments in industrial enterprises into the expansion of its own education network. The professor and architect Joris Helleputte from Leuven in this way was able to create a great number of quasi-public buildings for the Church, schools, and the university. It allowed him to join the ultramontanist movement, the counterreaction to the liberal bourgeoisie state that was beginning to take shape at this time, and which sought to tighten the connection with the Papacy ultra montes (over the mountains, the Alps), and to emphasize the unity of the faith in a new rich language of forms which resisted liberal and republican convictions. This enthusiasm about the city's medieval and Burgundian past was not limited to the university, but also led to a rigorous reconstruction of Leuven's city hall - an original piece from Brabant's late Gothic period in the fifteenth century in the form of a relic shrine made out of giant sandstones. The 'Neo-Gothics' filled the empty cavities with statues of historic heroes.

Even Antwerp, where the cityscape was after all strongly influenced by the Baroque visual language of the Spanish counterreformation and its hero Rubens, came to a newfound appreciation of its medieval past. The almost completely run-down decorations of the Grote 
Markt were refurbished in the Neo-Gothic style, and various quarters within the Renaissance city hall from 1563 were also redecorated in pseudo-medieval style. Even the harbor obtained Neo-Gothic headquarters, in between the Schelde and the Napoleon docks. At that time, the other side of the Napoleon dock still harbored the Renaissance Hanse House, dating from Antwerp's real economic golden age, the period from 1500 to 1585, when trade with the Baltic Sea area, England, the newly discovered continent of America, and the Mediterranean region pulsed through the city port of Antwerp. It was only in 1893 that the Hanse House would go up in flames. On its location the beautiful Museum aan de Stroom MAS now rises 60 meters high.

A key moment in the Neo-Gothic transformation of Antwerp, as well as in the much greater shift towards trade dependence in Belgium, was the re-opening of the Schelde in 1853. By transferring an impressive amount of gold to the Dutch Central Bank, the National Bank of Belgium was able to make the Dutch government declare that Belgium had now fulfilled all of its toll duties on the Schelde in perpetuity, in a quite weird international treaty. This move was followed by an economic boom that lasted several decades - a period in which impressive Neo-Gothic churches were built, such as the Sint Norbertuskerk on the Dageraadplaats in the art nouveau neighborhood of Zurenborg, and the Sint Willibrordus in the folksy neighborhood of Seefhoek. The enormous population growth in the cities put the conservative and clerical elites that had traditionally been dependent on rural incomes under pressure to incorporate the new social class of urban workers into a Catholic urban environment. The Neo-Gothic style offered a smart solution: industrialization was no longer to be radically denounced and resisted, but to be integrated into a life world and a visual language that connected to tradition and reflected a centuries-old order. In Antwerp this lead to an impressive urbanization. The old materials that remained from the demolition of the city walls to make room for the socalled Leien (large boulevards with bourgeoisie residences) were used to construct the railway overpass from Antwerp Central Station to Berchem in the style of a pseudo-medieval defensive wall. 


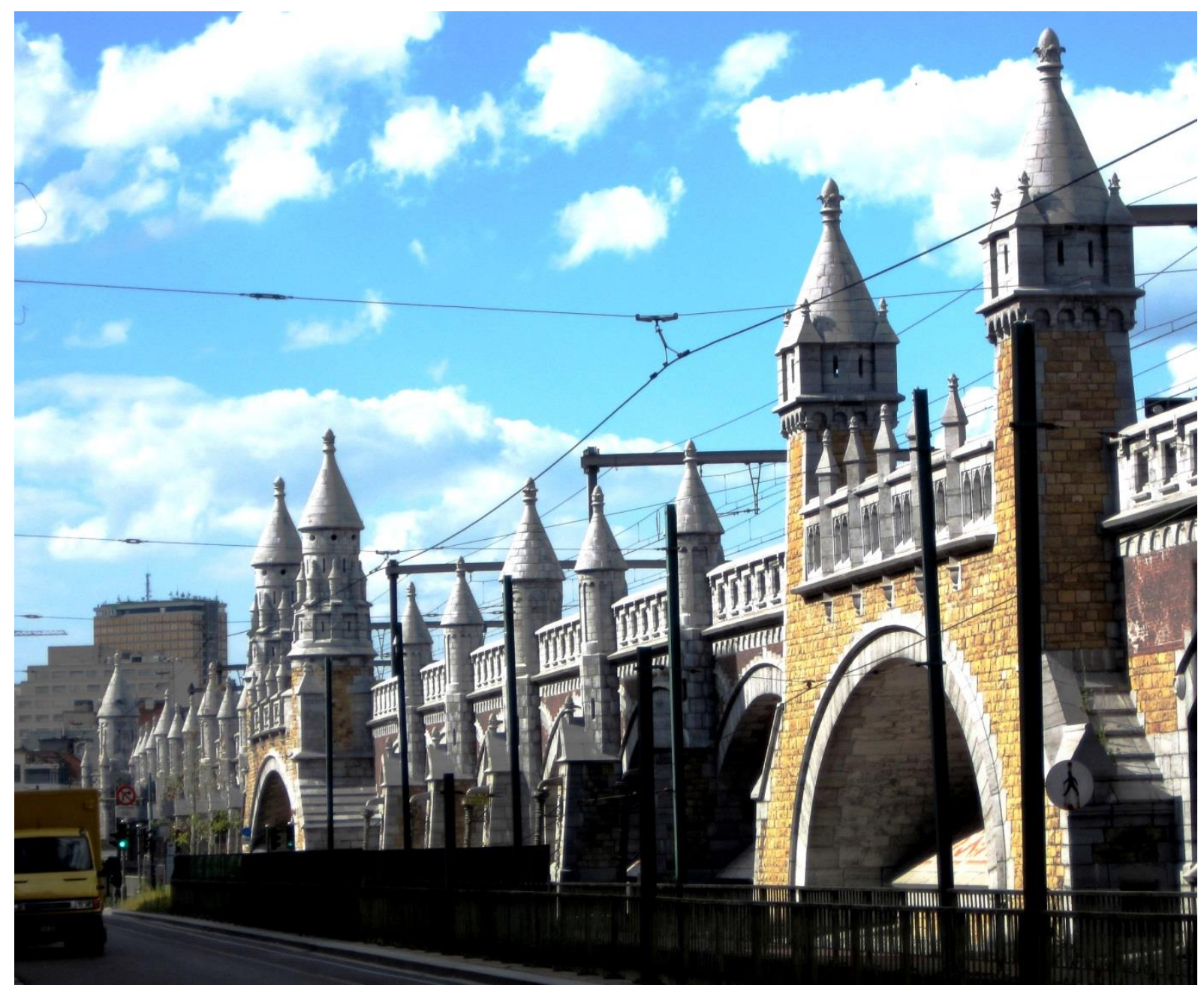

Illustration 4: railway overpass in the Antwerp Zurenborg district

In the Neo-Gothic Sint Joriskerk, in which the walls, pillars, and ceiling are completely polychrome, a series of murals depicts the self-image of a paternalistic and disciplining church that communicates her mission to the working classes (for the first time in Dutch!). And these workers were to be devoted, obedient, and industrious, following the example of a strong and resolute Christ.

Also the archbishopdom of Mechelen actively participated in the Neo-Gothic surge, even though the Baroque era would long cast a shadow over the city. In the rest of the country many schools and churches in this style also arose, often rapidly, and cheaply and industrially manufactured. Hence, many of these buildings were in a poor state only several decades later. Many were destroyed by the two World Wars, while many of the remaining buildings were ready to be demolished in the sixties and seventies or could by then only be restored with substantial government funding. It was in this way that a pre-modern and pre-democratic, pseudo-medieval visual language arose in Belgium that was primarily nourished by the vast income of the Church, and also the tax funds of a Belgian state that had royally profited from industrialization. It allowed the Belgian Catholic elite to present the image of an early urban culture north of the Alps that was the nec plus ultra of a golden age in which faith and the 
Church, trade and the Bourgeoisie, and craftsmanship and the workers supposedly lived in harmony in a well-organized, corporatist society.

The so-called monster alliance between the liberal and revolutionarily inclined financiers and industrialists from Brussels and Wallonia, and the Catholic elites from Flanders, was certainly a lucrative one for the Belgian Catholic church and its organizations. It formed the stable financial and socio-economic basis for a Neo-Gothic building spree over the entire country. The stability of this alliance at the elite level, allowed the Catholic party, the Liberals, and later also the Socialist Party, to serve as the pillars of the Belgian state. For the architectural representation of their power, the Liberals were much more inclined to turn to the 'enlightened' Neo-Classicism and Neo-Renaissance, than to the Neo-Gothic style of the - by them so much reviled - 'dark' ages. They built Neo-Classical and Neo-Renaissance athenaeum buildings, not Neo-Gothic monastery-like colleges. Later in the nineteenth century, when art nouveau was embraced by the liberal upper-class Bourgeoisie and prominent socialist urbanites, the Catholic middle classes and the Church retained their embrace of the NeoGothic style - all the way until the First World War.

\section{The Gothic Revival and Victorian eclecticism in Great Britain}

Britain's melting pot of aristocracy and bourgeoisie looked back with a mixture of fascination and abhorrence on the 'Dark Ages' of the violent, authoritarian Middle Ages in which knights from dark castles continuously battled one another. In its very beginnings however, the Gothic Revival had started out as a romantic movement that rejected all industrialization and advocated a return to nature and a 'natural' societal order. But as this all-out rejection turned out to be untenable, a hybrid and rather idiosyncratic version of the Neo-Gothic style arose on the British Isles.

The triumphant, industrial and liberal elites of Victorian England placed themselves above the sentiments of the Dark Ages, and looked with condescension on the ruins of these illiberal times in which neither freedoms and rights, nor trade and industry could flourish. Never mind that the English wool trade cities also, just like the Flemish and North-Italian medieval cities, had regularly liberated themselves from feudalism's tyrannical yoke. Many Victorian lords had a knack for constructing medieval ruins in their expansive gardens, as a reminder of these dark times dominated by robber knights and tyrants, which, thank goodness, had passed due to the arrival of parliamentary democracy and the industrial revolution. 


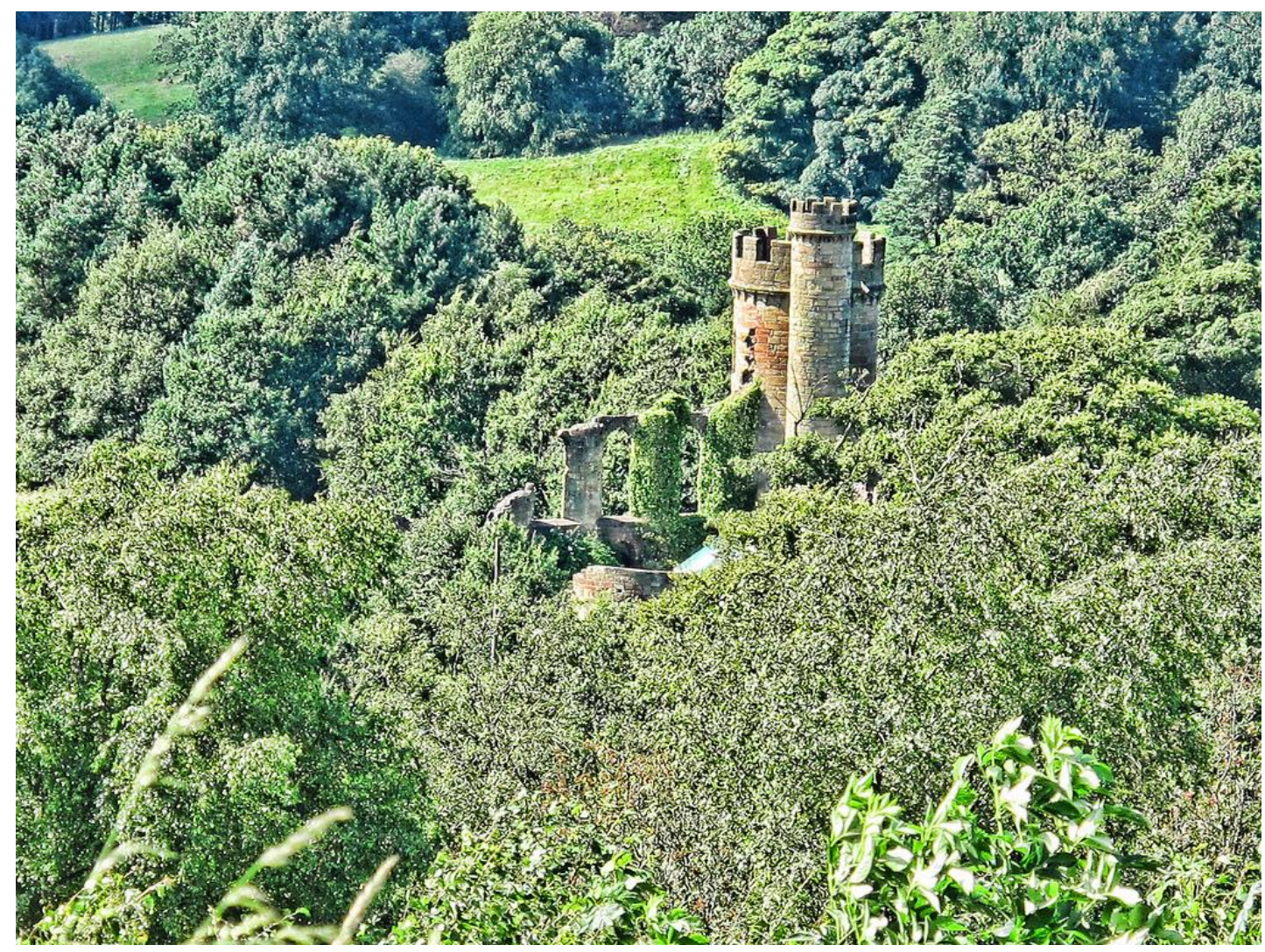

Illustration 5: 'sham ruin' or 'folly' Hagley Castle, well-viewed from Hagley Hall, itself in Palladian style, both designed by Sanderson Miller, middle $18^{\text {th }}$ century

After several decades, the British fascination for the medieval Gothic style progressed beyond that of knowing that it was a comfortable distance from a politically 'incorrect' past. Medievalism, infused with a dash of High Church Anglicanism and Catholicism, was an enormously influential movement that sought to counteract the merciless industrialization sweeping Britain and the coldness of rationalist and classicist thought. These developments were seen as dehumanizing and contrasted with the imagination of a golden, harmonious period in the Middle Ages: ecclesiastical, organic, and harmonious. This movement returned a building style to the capital of the British Empire that almost entirely gone with the destruction by the Great Fire of London of 1666. In its place had arisen the gruesome structures of the rationalist Baroque and Classicist movements.

The immense accumulation of riches from industrialization and the rapid urbanization of London that took place in the nineteenth century, offered the opportunity for realizing new architectural landmarks. The Law Courts, built between 1873 and 1882, were done completely in the style of a monumental abbey, including the pseudo-ruins of a cloister walkway. 


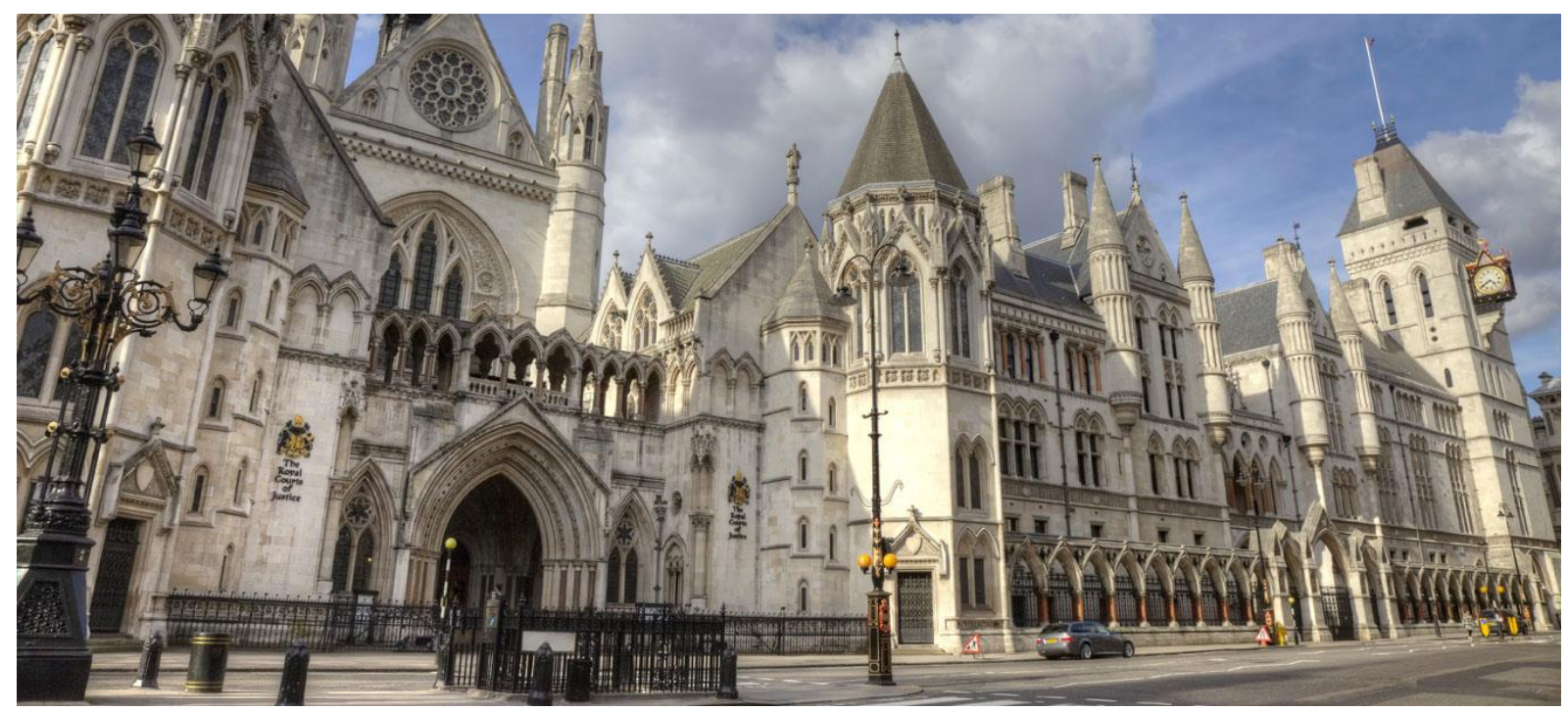

Illustration 6: The Law Courts, London, built 1873-1882 as if it were a medieval abbey.

The line structure of the immense Houses of Parliament (started in 1840) connects seamlessly with the late-Gothic Lady's Chapel on the backside of Westminster Abbey. No closed, martiallike structure, but a free expression of medieval church and abbey structures in an open and light complex of buildings, out of which Glorious England supposedly had been dominating the world seas for hundreds of years - though only Westminster Hall with its magnificent, enormous wooden roof support really stems from 1393. Somewhat later, the Victorian Londoners also invoked the Middle Ages of their imagination in developing a competition to connect both shores of the Thames at the height of the old prison, the Tower. Masonry with Gothic bows and little towers adorns the outside of a massive steel and industrial Tower Bridge, which possesses an ingeniously efficient and revolutionarily fast control system for its draw bridge.

Not just the capital of London acquired grandeur through Gothic architecture. A number of other cities that were also growing at a dazzling pace, attempted to create the illusion of an impressive past with historicized buildings that intended to connect to the Middle Ages. Manchester, for example, erected a Neo-Gothic city hall which was meant to provide the impression that it had been prominent city since the Middle Ages, though it did so only in 1877 when it had already long belonged to the industrial heart of Great Britain.

In Scotland a similar pompous style developed in various industrial cities such as Glasgow, though with its own unique accents. In what is known as the Baronial style, grand estates were erected that were supposed to resemble the impenetrable castles of the Middle Ages. In this manner, Scotland could continue its role as the somewhat old-fashioned, hierarchical outskirts of the Kingdom which had not yet tasted the refinement and civilization of open estates and light-hearted, elegant urban houses. The gothic novel, Anglo-Saxon haunted houses, gothic music and clothes, and the mythical medieval past as depicted in movies serves as lively recollection of this $19^{\text {th }}$ Century tradition, not the least in the United States. 
How do these national variations on the Neo-Gothic style connect to trade theory about political coalitions? The increasing trade of the nineteenth century produced various socioeconomic elites that seized governmental and state power, sometimes through coalitions and sometimes not. While the landed aristocracy during and after the Napoleonic Wars still controlled British government, its power was gradually diminished by the expansion of the suffrage through the Reform Act of 1832, the elimination of the protectionist Corn Laws in 1846, and the Cobden-Chevalier trade agreement of 1860 between France under Emperor Napoleon III and the government of the reformer Robert Peel. In comparison to France and the United States, this made land as a production factor for agricultural resources relatively scarce in the United Kingdom. The great British cities now had access to more and cheaper grain, without excessive customs fees, because it could be transported via train and boat from France or the American Great Plains to Liverpool and London. At the same time, the industrial and trading classes amassed a tremendous amount of capital, and a great number of superfluous agricultural laborers moved en masse into the industrial sector. Gradual trade liberalization thus benefited both capitalists and laborers in the long term, at the expense of those who obtained their income from laboring the land. In Belgium, a similar process was transpiring, particularly after the Schelde had been freed from toll duties, which allowed Antwerp once again to become an important intra-European and colonial harbor. To be sure, this socio-economic transformation occurred later in Belgium than in Great Britain, and had a somewhat different form. The so-called monster alliance between the Liberals and the Catholics assured that the Church and rural elites could participate in government and exert control over the national coffers, which enabled Catholic landowners to invest their profits in new industrial ventures. In addition, the rural-conservative side saw the need to provide a political response to the success of the workers' cooperatives that had been arising and to the foundation of the Belgian socialist party in 1885. After its bad experience with attempting to suppress Daensism (a Flemish catholic trade unionist movement in the textile city of Aalst), the church founded its own catholic workers' movement as a way to compete, and to maintain its connection to the growing urban population. The Neo-Gothic building style - industrial, quick, large scale, and still reminiscent of an imagined past, offered the most befitting visual language.

What a difference with the situation of the numerous laborers in the densely populated areas of Germany, which in the first half of the nineteenth century were both poor in capital and in land. Both the Junker landowners and the few early capitalists had protectionist tendencies and feared the competition from, amongst others, Great Britain and Belgium if trade barriers were abolished. The elimination of the internal German customs barriers was enough for them. They feared both the massive amount of available capital in industrialized Great Britain and Belgium, as well as the competition from the greater number of laborers in Britain and densely populated Belgium. In this way, the German Empire saw the rise of a regime of defensively-minded industrialists in the West and protectionist landowners in the East - the 
so-called Bündnis aus Roggen und Eisen - which under Reichskanzler Bismarck fought stubbornly and with great success against the participation of the socialists in government. The latter were deprived of governmental participation until after the First World War, which - not surprisingly - led to a much more acute radicalization of the labor movement than in Great Britain and Belgium.

Seen from the perspective of political trade theory, it is notable how the Neo-Gothic movement in Germany, Belgium, and Britain showed substantial variety. The political coalitions that attained state power, left their mark in the ways they tried to legitimize their rule through architectural forms. The accepted view that the Neo-Gothic movement had a uniform visual language throughout Europe, attests to the success of the various national elites that attained governmental power and who were able to impress a uniform image of their imagined Gothic Middle Ages.

\section{References}

Ronald Rogowksi (1989), Commerce and Coalitions. How Trade Affects Domestic Political Alignments, Ithaca: Cornell University Press. 